\title{
Crafting the Effective Learning Model for High Education: An Investigation from the business Incubator in Three Universities in Indonesia
}

\author{
Nila Krisnawati Hidayat ${ }^{1} \&$ Alfi Andri ${ }^{2}$ \\ ${ }^{1}$ International Business Administration Department, Swiss German University, Indonesia \\ ${ }^{2}$ Accounting Department, Swiss German University, Indonesia \\ Correspondence: Alfi Andri, Accounting Department, Swiss German University, Indonesia.
}

Received: September 6, 2017

Accepted: October 16, 2017

Online Published: November 16, 2017

doi:10.5430/jms.v8n5p18

URL: https://doi.org/10.5430/jms.v8n5p18

\begin{abstract}
The study aims to examine the current implementation of entrepreneurship learning including business incubator and to identify factors influencing the effectiveness of entrepreneurship and incubator output including developing collaborative learning model in each particular faculties/university in Jakarta and Tangerang. Method of the study uses qualitative analysis which is focusing on Focus Group Discussion (FGD) and in -depth interview approaches to eight universities and fifteen academicians with strong background in managing as well as entrepreneurship teaching experiences. The result shows that strong collaboration between the study programs and business incubator must be strongly established to provide entrepreneurship learning experiences in higher education. There are significant aspects as influencing factors to create collaborative model between entrepreneurship program and business incubator; university's vision and mission, entrepreneurial background lecturer, strong culture and reward system. This study is claimed as few studies focusing on developing a collaborative model specifically to the universities which have business incubator in Indonesia. Studies on the effect on collaborative learning model on entrepreneurship toward succesful entrepreneurship education would be considerably fill in the gaps in the body of knowledge on the subject
\end{abstract}

Keywords: enterpreneurship, business incubator, collaborative learning model

\section{Introduction}

\subsection{Introduction}

Etzkowitz (2000) stated that the two main activities delivered by the traditional university are teaching and research. However, there was a new approach to the role of universities visualizes a structural shift from their traditional to the commercialization of new knowledge for economic development. Most universities have been paying attention on the creating and implementing these new approaches becoming entrepreneurs universities. They do belief that entrepreneurship program is dynamic and flexible to strengthens students' life pathways, including personal growth, social participation and the value sharing development. Through the entrepreneurship program and activities, universities gain the benefit to foster entrepreneurial spirit and skills including encouraging young generations to establish their start up business. Storen (2014) have founded through her research in Norway that graduates who have had entrepreneurship education are not more frequently self-employed than other graduates. Therefore, education should increase entrepreneurship awareness from primary school to university (Rybnicek et al., 2015). Introducing young people to entrepreneurship triggers their initiative and helps them to be more creative and self-confident (European Commission, 2006).

The significance of entrepreneurship education has been growing ever since the first entrepreneurship class was held in 1947 in the USA, and especially from the 1980s on, when Drucker's Innovation and Entrepreneurship was published (Drucker, 1985; Katz, 2003). In another hand, the existance of business incubator is an important tool that can be used by universities to support new start-ups and spin-offs, as well as to build links with industry (EC/OECD, 2012). It becomes the obligation of business incubators to nurture the creation and development of the new, innovative, sustainable companies by providing prospective business conditions (Bikse, Veronika et al., 2016). These findings show the critical role of business incubator for the higher eduction in achieving the succesful of 
entrepreneurship program.

\subsection{Problem Statement}

From the description above, the critical problem founded is determining the methods that should be designed to teach entrepreneurship. In many universities, entrepreneurship is commonly taught as one of the subjects, more over, it is even still taught as an elective subject. In the business school, entrepreneurship has grown to become one of the majors. But at the university level, only few universities have adopted entrepreneurship courses that involve students from various departments, whereas entrepreneurship so far is best taught by using multidisciplinary approach and engage with their business incubator. The study method still remains unimproved, since the collaborative learning model is still not available yet. The objective of this paper is two fold. Firstly, we examine the current implementation of entrepreneurship learning including business incubator in particular universities. The second objective is to develop the collaborative learning model of entrepreneurship between its current curriculum and existing incubator in particular faculties/universities.

\subsection{Literature Review}

According to Drucker (1986) entrepreneurship is a discipline, and like any discipline, it can be learned. Gorman, Hanlon and King, as cited in Kuratko (2005) showed that most of the empirical studies surveyed indicated that entrepreneurship can be taught, or at least encouraged, by entrepreneurship education. Studying the impact of education on the creation of future entrepreneurs, Raichaudhuri (2011) concludes that the great majority of empirical finding support the legitimization process of entrepreneurial education, and indicate that entrepreneurial aspiration and success can, in fact, be taught through suitable education programs. Teaching entrepreneurship is not just about teaching how to create a business plan or creating a new business, it should also emphasize in developing entrepreneurial skills. Based on the research conducted in China on the entrepreneurship education, Ge and Li (2015) stated that it was being in transition period from exclusive to the mass education stage. It has also become an important task of colleges and university allows students alert with the knowledge; skills transfer into entrepreneurial qualities, knowledge and skills to the conversion capacity of material wealth.

The effective entrepreneurship education is not about teaching how to start a new business, but effective entrepreneurship education delivers the development of skills and competencies associated with successful entrepreneurship. Entrepreneurial education must include skill-building courses which including negotiation, leadership, new product development, creative thinking, and exposure to technological innovation. In teaching entrepreneurship, types of learning tools consist of: business plans, student business start-ups, consultation with practicing entrepreneurs, computer and behavioral simulations, interviews with entrepreneurs, environmental scans, field trips and the use of video and films Jesselyn and Mitchell, noted that while passive learning (lectures and expert talks) may be adequate for other subjects it is believed that entrepreneurship has to be mainly based on, or at least supplemented with, action based, experiential learning.

Vesper and Gartner (1998) claimed that research on entrepreneurship education have focused on progress in Entrepreneurship Education, including the courses delivered in the UK and USA (McKeown et al., 2006; Solomon, 2007), indicating the diversity of courses in terms of content and methods. While the finding of similar research in Malaysia conducted by Cheng et al. (2012) revealed that entrepreneurship education was not matching students' skill expectations with skill acquisition. It also shown that the level of understanding toward entrepreneurship considered low among the selected respondents. Conversely, the findings deliver valuable insight for further teaching development of entrepreneurship subject in that country. Different with entrepreneurship education offered by India's management and business administration programs universities both undergraduate and post graduate, the focus was to expose young people's mind through development of project profile as learning outcome (Joshi, 2014). Separately from the entrepreneurship teaching approach, the syllabus and course development of this subject has been a debatable area. However, there is an obvious recognition from many universities worldwide that entrepreneurship education is emergent as an academic discipline. The objectives of Entrepreneurship learning could be classified into the range of creating level of awareness, entrepreneurial skill development to teaching of specific business related knowledge. It can be concluded that the objective of entrepreneurship learning provides a great impact on the overall program.

\subsection{State Hypotheses and Their Correspondence to Research Design}

According to Directorate General of Higher Education in Indonesia, called DIKTI, the budget allocation to support entrepreneurship program in 2009 through grants delivery was around 37 billions rupiahs (Adrianti, 2009). The government uses this fund for students entrepreneurship program. There were consisting of some private universities, 
polytechnics and state universities such Gadjah Mada University, Bandung Technology Institute, Indonesia University, Airlangga University, Bogor Agriculture Institute, and Diponegoro University. At the university level, only few universities has adopted entrepreneurship courses involving students from various departments, whereas entrepreneurship so far is best taught by using multidisciplinary approach. All of these show that entrepreneurship education in higher education in Indonesia is still at the early stage. This early stage should be continued with a more integrative long term program to gain desired results. Indonesia needs to build a national plan in entrepreneurship education involving students from elementary schools into universities. Many studies have explained on the conceptual model of entrepreneurship in education and found the fact that there were confusion in conceiving entrepreneurship and the methods used to teach it. However, there were no shared understandings to conceptualize the model as an integration of two domains: entrepreneurship and education. Poloniemi (2012) stated that in universities, entrepreneurship education teachers tend to either adopt the discovery theory or follow their own instincts originating from their everyday observations of how entrepreneurs seem to manage their businesses. As a result, entrepreneurship educationze teachers typically concentrate on how to run a business rather than how to create new business opportunities or how to create a new business

\section{Method}

The study conducts qualitative study, which analyzed the implementation of entrepreneurship program at the universities by conducted indepth interview and focus of group discussion. The pilot study was conducted in order to obtain broader view of the study such as, research problem, participation and sample of the study.

Referred to Calitz (2009), a pilot test of questions assists to identify unclear or ambiguous statements in the research protocol while Van Wijk and Harrison (2013) believe that pilot studies can add value and credibility to the entire research project. The reseracher has conducted the pilot study by preparing the questionaires as a guideline before the in depth interview. The resesearchers identified potential problems and areas that may require adjustments. It is done just before preparing the questionnaires. This stage was taken to avoid ambiguities, difficult and unnecessary questions and discard or modify same. Distributed the questionnaire to number of participants including students from Business and administration program study provide the assumption that entrepreneurship subject alone does not effective to encourage student to be real entrepreneur without any futher actions taken, in addition, business incubator unit should exist.

\subsection{Participant (Subject) Characteristics}

The population of the study consists of the higer education institutions or universities which have active business incubator as their supporting facilities located in Jakarta and Tangerang The observations and literatures shown that universities with the incubator business were Universities of Indonesia, University of Bina Nusantara, University of Multimedia Nusantara and Swiss German University. In addition the study took all of the population (census). Based on the report from The Deputy Ministry of Micro, Small \& Medium Enterprises (M/o MSME), there are about twenty four active universities from sixteen provinces in Indonesia developing the MSME (Solopos.com, 2013). Universitas Diponegoro Semarang, Jawa Tengah, Universitas Lambung Mangkurat, Kalimantan Selatan, University of Indonesia, Univeristy of Bina Nusantara - Jakarta, University of Multimedia Nusantara, Jakarta, Universitas Surya Kencana Cianjur, Jawa Barat, Universitas Muslim Indonesia Makassar, Sulawesi Selatan, IPB Bogor, ITB Bandung, UGM Yogjakarta, Ikopin Sumedang, UNS Solo, ITS Surabaya, Unibraw Malang, UNY Yogyakarta, Udayana Bali, UN Gorontalo, USU Medan, Unand Padang, Unri Riau, Unhaluoleo Kendari, University of Jambi, Universitas Syah Kuala, and Business Technology Center Batam. However, there are no particular sample size must be taken for the type of case study in the qualititave research as explained by Creswell (2013).

\subsection{Sampling Procedures}

There are eight universities and fifthin academicians who have background in managing and teaching the entrepreneurship. The study conducted only to the universities which have business incubator i.e., state universities and private universities in Jakarta and Tangerang. The study used Focus Group Discussion (FGD) which Wilkinson, (2004, p. 177) explained that focus group research is "a way of collecting qualitative data, which is essentially involves engaging a small number of people in an informal group discussion (or discussions), 'focused' around a particular topic or set of issues" Focus group discussion also considered less threatening to many research participants, and this setting is useful for participants to discuss perceptions, ideas, opinions, and thoughts (Krueger \& Casey, 2000). Beside FGD, as Cresswell explained above that the data collection could also been taken through in depth interviews. The questions were listed and focused on (1) the current program of entrepreneurship integrated with its business incubator, (2) the collaborative learning model between entrepreneurship program and business incubator 


\subsubsection{Unit Analysis}

Unit analysis of this study are the entity/organization (univesities) located in Jakarta and Tangerang which active the business incubator

\subsubsection{Research Design}

There are stages shold follow in the qualitative study that explained by Creswell (2013)

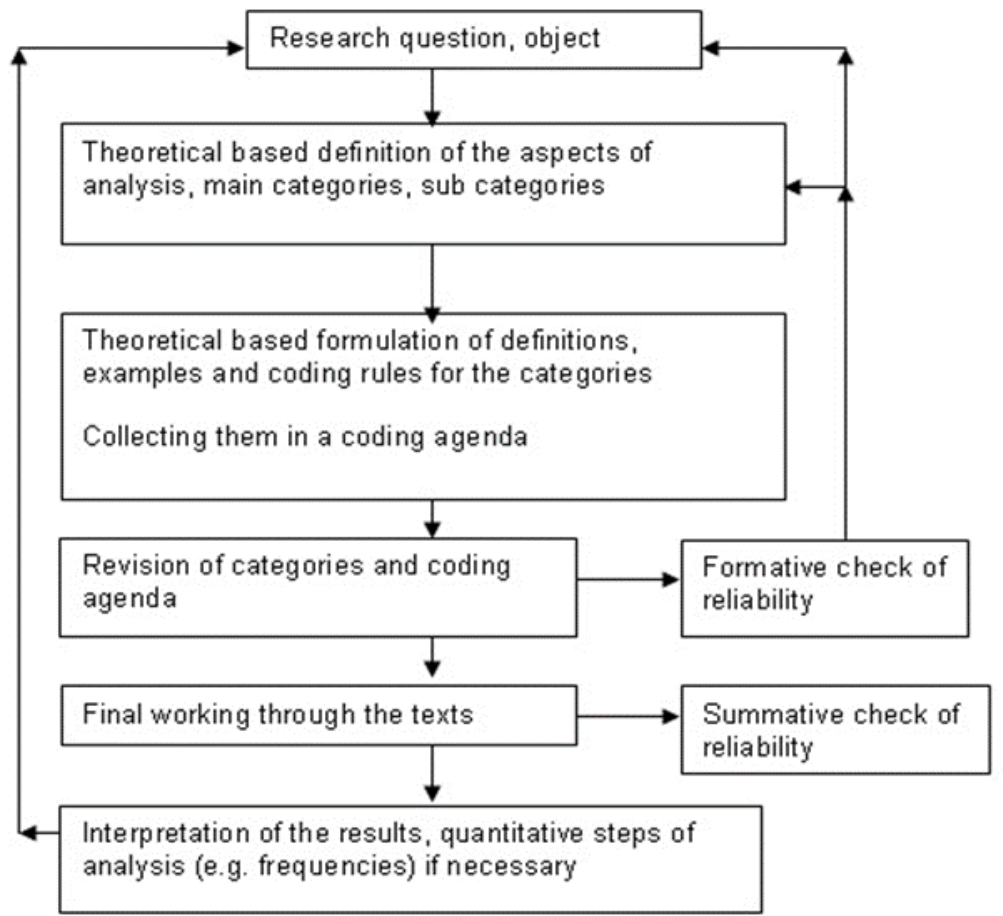

Figure 1. The research desigh for qualitative research

Source Creswell (2013)

As shown in Figure 1 explained some critical stages must be taken from preparing and designing the questions and supported by the strong fundamental theory. Then, the result of data collection must be explored through coding or summarizing approach. The final stage is intepretation of the result to achieve objective finding of qualitative research.

\section{Results}

\subsection{Brief Profile of the University Business Incubator}

These universities were taken as potential sources at this study to explain the current condition and implementation of entrepreneurship learning including business incubator in particular faculties/universities. There are three universities; University of Indonesia, University of Bina Nusantara and University of Multimedia Nusantara. The brief description of those universities are explained below

\subsubsection{University of Indonesia - Directorat Business Incubator}

One of the activities of Directorate of Business Incubator at UI is assisting the students from various levels, especially students who just want to start a business. This is done through mentoring, business class, simulation, and business networking at the internal, national, and international levels. Furthermore, to maintain the business atmosphere, DIIB collaborate with Center for Entrepreneurship Development \& Studies (CEDS) brings together alumni who have successfully done business with new members every year. As one of the first business community among universities in Indonesia, CEDS delivers its members to become a reliable businessman in various sectors.

\subsubsection{University of Bina Nusantara - BINUS Startup Accelerator}

BINUS University is exploring and seeking a synergistic partnership with the aim of maintaining the relevance of BINUS' education in the globalization era and of closing the gap between BINUS' curriculum and industry needs. 
With an enormous numbers of resources, which consist of experts, knowledge, technology, and creativity, we are here to give our insights and solxutions for every needs and problems within your organization. BINUS Creates acts as a 'hub' that connects the faculties with external parties and vice versa. The best way to learn is by doing. BINUS Start Up Accelerator is a series of pitching-mentorship program for BINUSIAN active students in pursuing entrepreneurial spirit and experiences to potentially scale the business in the market. Through an open application process, students who apply BINUS Startup Accelerator will get several advantages: Free training and enhancement programs for every role. Students who are in semester 7 or 8 can transfer the project as an internship program or thesis. The Accelerator will pick potential startups and get them for a 12-week-acceleration program. There we provide mentorship, access to office facilities, series of company building activities, go-to-market support, and seed funds for the winning team. At the end of the program, a Demo Day will be held for the startups to meet and pitch in front of the investors

\subsubsection{University of Multimedia Nusantara - Skytar Ventures}

Skystar Ventures is a tech incubator and coworking space founded by Universitas Multimedia Nusantara (UMN) and Kompas Gramedia Group (KGG). They target early stage startups in the Internet, mobile, social, education, and eCommerce sectors. Startups that disrupt traditional models excite them. More importantly, they seek out founders who are dedicated to making a positive impact in Indonesia. Their comprehensive incubation program enables them to provide direct and multidisciplinary support to founders, enabling accelerated growth. The diverse network of mentors help founders obtain the guidance required to build thriving companies. They also provide coworking space for our founders to utilize for work, meetings, and conference space. Backed by one of the largest media groups, Kompas Gramedia, They are able to provide founders access to their unrivaled network of media and business units in multiple industries to help grow and scale the business. They are committed to providing the resources required to help startups create sustainable businesses in Indonesia.

\subsection{Respondent Profile of Focus Group Discussion (FGD)}

The profile of FGD held in Ibis Hotel Serpong at February $24^{\text {th }}$, 2017. There were attended by universities representatives in Jakarta, Tangerang and Depok area

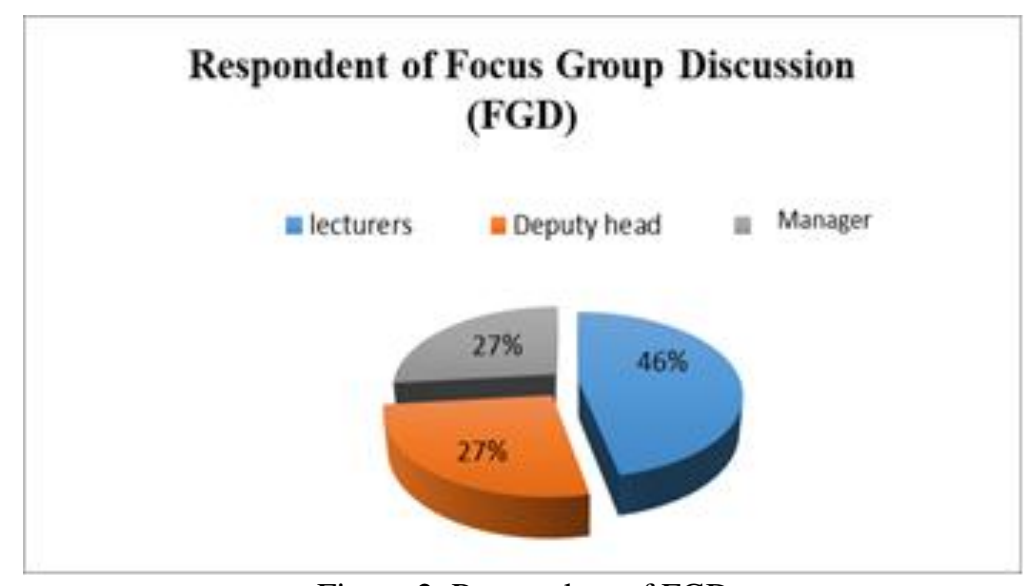

Figure 2. Respondent of FGD

As shown in Figure 2, the participant in the FGD. The FGD participants are 15 participants, they are mostly come from private universities. Seven participants are lecturers (46.66\%), four participants are deputy head of business $(26.66 \%)$ and four participants are the manager/director of incubator $(26.66 \%)$.

\subsection{The Implementation of Current Program of Entrepreneurship with the Business Incubator}

The skill of entrepreneurs requires hard work as it is stated by Karyana (2016), Yovita (2016) and Nurul (2016). The university must design their own vision and mission to achieve their goal in related with their involvement on the development of entrepreneurship in Indonesia. First is the formation of student mindset. The students need to be equipped with understanding of entrepreneurship and entrepreneurship accompanied by appropriate field exercises. Some universities abroad in America, Europe and Asia have sought to develop entrepreneurship education models, but entrepreneurship education is strongly influenced by local culture. The European model is not appropriate if 
applied in Asia. Korean model, not necessarily suitable if tested in Singapore. Similarly, the Indonesian nation must find a suitable pattern in this entrepreneurship education. In fact, the condition between the state and private university are also influence the implementation of entrepreneurship education in Indonesia (Karyana, 2016, Yovita, 2016 and Nurul, 2016)

\subsubsection{The Implementation of Entrepreneurship Subject and Business Incubator in the State University}

The entrepreneurship subject is mostly under each department or study program. However, to achieve the effectiveness of that subject it will be linked with the existence of business incubator. The business incubator directorate is managed under the university level, specially under the vice rector in charged for the collaboration and business development field or in charged for the research and innovation activities. The function of its directorate is to formulate policies and innovation development, business incubator management and intellectual property rights process and curriculum development that encourages innovation and entrepreneurship development within the academic community of Universitas Indonesia (Nurul, 2016). The task is divided into three areas such as Innovation Development, Business Incubator and Intellectual Property and Promotion. The mechanism flow is based on the downstream of research. The potential researchers and shows their willingness to be a start up, then it should go into the incubator. However, for the research with the concern on a license, they will be ended at the intellectual copyright process called HAKI (Hak Atas Kekayaan Intelektual). Inventors go for start up and want to build their own business, will be assisted by the incubator directorate.

There are also potential incentive program provided to selected students in the university level. Total intensive mentoring program is nine months, collaboration with cooperation with coaching business, consist of several stages/phases. Phase I: after registration they are collected in booth camp activities. They are the ones who pass the selection. Participants who do not attend will be eliminated. Phase II: interview or presentation. In 2016, there were about 14 selected groups, and 9 potential groups were continue and passed to next level. Most of them have ICT project. Phase III: After winning, there is "Mentoring". From 65 groups, usually only 14 could be passed the selection process (25-30\%). Entrep Camp II: Focus to the winners. They have an obligation to maintain the business. Therefore, there focus of training are on Business Canvas and finance dashboard ( 3 days 2 nights). Output: Business Plan including the incentive (cash money) as a reward. There are many cases described through in depth interview on the entrepreneurial subject and implementation in each observed university. Most of them are showing the role of the university in establishing their vision and mission to achieve the goal, which is related with the entrepreneurship implementation. Another factors are the existence of infrastructure as well as the resources such as the lecturers.

\subsubsection{The Implementation of Entrepreneurship Subject and Business Incubator in the Private University}

Despite of the state universities, the private universities are more independent and commercial in implement mechanism of enterpreneurhip and business incubator. Bina Nusantara, The Entrepreneurship is managed under University level, in this case is Vice Rector in charged for the corporation affairs. The percentage of entrepreneurship subject currently is added into bigger portion. Subject entrepreneurship is not enough 2 (two) credits, so it is increased to six credits and become compulsory subject, divided into 4 courses, in semester $3,4,5,6$. The vision is to provide experience on entrepreneurship perspective from the theory to the practice of doing small business and conducting market test. This course is embedded into other subjects such as statistics. This indirectly educates the lecturers to find ways for lecturers to discover how students learn entrepreneurship and this is easier to deliver entrepreneurship. Multimedia Nusantara on the other hand, there is subject of entrepreneurship. However the vision is definitely solid, to create the competent technopreneurs in the future.

The mechanism on the subject entrepreneurship in Bina Nusantara is well structured. the entrepreneurship 1 the students are required to create concept and make the product as prototype. Semester 2: business project. Semester 6, it is propose to create programs that can be taken by all study programs, for example is $3+1$ (elective) program. 3 years of college and 1(one) year looking for experience. Multimedia Nusantara on the other hand, the business incubator is creating to support the students who are willing and have a passion in entrepreneurship. The incubator, called Skystar Venture and it is very active in assisting the students to increase their capacity building through soft and hard skill. The soft skill focused to be increased including critical thinking, project management, communication. The hard skill covers the understanding on particular knowledge such as Business Canvas Model (MNC) and Information Communication Technology (ICT). Skystar Venture (SSV) already has 3 batches of graduates, from three years ago since 2013. The potential participants are mostly come from semester five students. However, the awareness and socialization program have been running since the students were in the early semester. UMN does not oblige them to participate. That's the challenge that the incubator should do to attract the students. The incubation period is arranged from 4-6 months, and they will be given a working space. The participants show a great progress 
they can still stay at the working space and gained some assistances and mentoring from incubator.

3.3.3 The Collaborative Learning Model Collaborative Learning Model between Entrepreneurship and Business Incubator

It is necessary to develop the collaborative learning model to assist the university achieves their goal and objective in related with their potential resources of entrepreneurship program and existence of their business incubator. In addition to this, the design analysis consists of few stages

\subsubsection{Preparing and Designing the Questions}

The questions are preparing match with the research objective. The research objective is to develop the collaborative learning model of entrepreneurship between its current program and existing incubator in particular faculties/universities. Therefore Core Questions are following, firstly, how is the current program of entrepreneurship integrated with its business incubator, secondly, what are the factors influencing effectiveness of entrepreneurship program and business incubator, thirdly, how to create the collaborative learning model between entrepreneurship program and business incubator?

\subsection{Focus Group Discussion (FGD)}

To support finding of study, focus group discussion (FGD) conducted. The content of FGD summaries below.

Tabel 1 . How is the current program of entrepreneurship integrated with its business incubator

\begin{tabular}{|c|c|}
\hline Description & $\begin{array}{l}\text { Participant } \\
\text { code }\end{array}$ \\
\hline $\begin{array}{l}\text { The universty have decided to embedded the entrepreneurship activities into curricullum } \\
\text { integrated with business incubaator. The credits are more than } 4 \text { credits. Student must provide the } \\
\text { project in group and it can be considered as an option for a thesis before they graduate from } \\
\text { studying. }\end{array}$ & $\mathrm{KH}$ \\
\hline $\begin{array}{l}\text { It was delivered as one of subject curricullum for particular semester, however it was not } \\
\text { mandatory for joining business incubator. The credits of this subject are less than } 4 \text { credits. Only } \\
\text { those have interested will join the business incubator program. }\end{array}$ & NS \\
\hline $\begin{array}{l}\text { We did not set the entrepreneurship subject into one of incubator business program. However we } \\
\text { provide significant activities for those who will join the program and at the end it can be weaved } \\
\text { as the score for the entrepreneurship subject with particular terms and condition. The credits for } \\
\text { entrepreneurship subject is } 3 \text { credits (management) and } 2 \text { credits (non management) }\end{array}$ & $\begin{array}{l}\text { YS, } \\
\text { BM,HR, } \\
\text { IR }\end{array}$ \\
\hline $\begin{array}{l}\text { On the digital marketing consentration the total credits up to } 24 \text { credits. Each study program is } \\
\text { different. The students must present their project in front of the venture, but is not integrated yet } \\
\text { with the incubator. }\end{array}$ & $\begin{array}{l}\mathrm{RR}, \\
\mathrm{SK}\end{array}$ \\
\hline $\begin{array}{l}\text { The entrepreneurship subject has } 7 \text { credits and disentralized through each study program. It is not } \\
\text { integrated with business incubator yet, since we faced challenges in term of participants' culture } \\
\text { who are majorely employeed students. }\end{array}$ & $\begin{array}{l}\text { IG, } \\
\mathrm{MH}\end{array}$ \\
\hline $\begin{array}{l}\text { With } 3 \text { credits under each study program, the entrepreneurship subject has been setting based on } \\
\text { two models; lecturing and project. However it doesn't integrated yet with incubator business. }\end{array}$ & $\begin{array}{l}\text { HD,RN, } \\
\text { IM }\end{array}$ \\
\hline $\begin{array}{l}\text { The subject is } 2 \text { credits and delivered at semester } 5 \text { and } 6 \text {, assessed through written and project. } \\
\text { However we haven't set the subject into incubator, but more to tracing the the student after they } \\
\text { graduate from university. }\end{array}$ & MK \\
\hline $\begin{array}{l}\text { We have } 8 \text { credits spread at some semesters. At the end they have to prepare the project through } \\
\text { subject entrepreneur venture at semester } 5 \text {. The subject does not integrated yet, however those } \\
\text { with excellent performances are recommended to continue to the business incubator. }\end{array}$ & MR \\
\hline
\end{tabular}

As shown in Table 1, that not all universities integrated the existence curricullum or subject of entrepreneurship with the business incubator. The universities somehow face some challenges such as budget and resources. It is relevant with the previous studies conducted by Wiratno. S (2012), that one of the challenges faced by the universities is the 
limited facilities and infrastructure for entrepreneurial activities. However, all the participants at the FGD stated that they are willing to establishe the entrepreneurship centre as well as the incubator to make the program much more effective. Most of them, actually realized that the government support is already increasing to support the program. And they also emphise on the role of foundation and the university to establish the existence of entrepreneurship centre and the business incubator. It can be achived by reviewing the vision and mission including the goal and objective of the university toward the effective entrepreneurship and incubator.

Tabel 2. What are the factors influencing effectiveness of entrepreneurship program and business incubator

\begin{tabular}{lc}
\hline \multicolumn{1}{c}{ Description } & $\begin{array}{c}\text { Participants } \\
\text { code }\end{array}$ \\
\hline $\begin{array}{l}\text { The university support and lecturer are necessary for implementing the succesful entrepreneurship } \\
\text { and incubator program and activities. }\end{array}$ & KH \\
\hline $\begin{array}{l}\text { The mechanism/system will bring the lecturer and students easy to accomplish each goal and } \\
\text { objective of entrepreneurship and incubator program. }\end{array}$ & NS \\
\hline $\begin{array}{l}\text { We have to create "the bridge" to understand and increase the passion and awereness of the } \\
\text { students about the entrepreneurship and business incubator's role. And also great lecturer who } \\
\text { could motivate them to think out of the box. }\end{array}$ & BM,HR, \\
\hline $\begin{array}{l}\text { Lecturers ar every important to make the succesful of entrepreneurship program. Beside that, } \\
\text { environtment could shape the mindset of the students too. }\end{array}$ & SR, \\
\hline $\begin{array}{l}\text { Having a project with inspiring lecturers are very critical for the successful learning } \\
\text { entrepreneurship program and activities }\end{array}$ & IG, \\
\hline $\begin{array}{l}\text { Background and culture of the participants (students) are influencing factors of an effective } \\
\text { business incubator program }\end{array}$ & HD,RN, IM \\
\hline $\begin{array}{l}\text { The students need to have a real role model. } \\
\text { It is really necessary to set up great curriculum to attract the students and support from all related } \\
\text { departments. }\end{array}$ & MR \\
\hline
\end{tabular}

As shown in Table 2, the university culture and the lecturers are very crucial to support the effectiveness of entrepreneurship and business incubator. The universities with strong background of entrepreneurship come from their founder and/or students as learning participation are mostly easy to establish the entrepreneurship and business incubator. These findings are also relevant the previous study from Chao and Li (2005) who stated that the core entrepreneurship education actually is to train college students entrepreneurial awareness, entrepreneurial quality, entrepreneurship, entrepreneurial skills and entrepreneurial abilities. Therefore, the university requires to establish the culture as well as preparing the potential lecturers.

Tabel 3. How to create the collaborative learning model between entrepreneurship program and business incubator

Description Participants

code

The university support is critical to succeed the effective learning of entrepreneurship. The KH lecturers will comply with the university's policy to run any single program including for entrepreneurship and incubator.

The university play a vital role to create effective mechanism for the succesful model. It is very NS hard for thelecture and incubator staff to run the program without it.

The incubator must have a strong and clear concept to enggange with university's mission and YS, vision. It will stimulate both parties to create many program that stimulate the students' passion BM,HR, and reward them for every effort they have shown. 
Effective mentoring could be delivered to create effective learning between the students and RR, lecturer. Therefore the result could be proceed further in incubator.

SK

The model could be developed only if the lecturers are potential with the strong background in $\quad$ IG entrepreneurship. It must be supported too by the university.

$\mathrm{MH}$

\begin{tabular}{ll}
\hline The university must established curriculum which connected with the incubator & HD,RN, IM \\
\hline It must be started by the vision and mission from the university level before. & MK \\
\hline $\begin{array}{l}\text { Reward system for the students who have a great project and involvement at their business } \\
\text { plan/project, supported by the management. }\end{array}$ & \\
\hline
\end{tabular}

As shown in Table 3, it is concerning to the establshing of the collaboarting model which is not existing yet. As Poloniemei (2012) confirmed that the current Education Entrepreneurship model typically concentrate on how to run a business rather than how to create new business opportunities or how to create a new business. It is strengthening the fact that actually the collaborating model is not existing yet in the hidger education communities/industries.

\section{Discussion}

Based on result above the collaborative model between entrepreneurship program and business incubator must consider following critical aspects namely, the university's vision and mission, lecturer commitment, strong culture and reward system. It showed in the figure below.

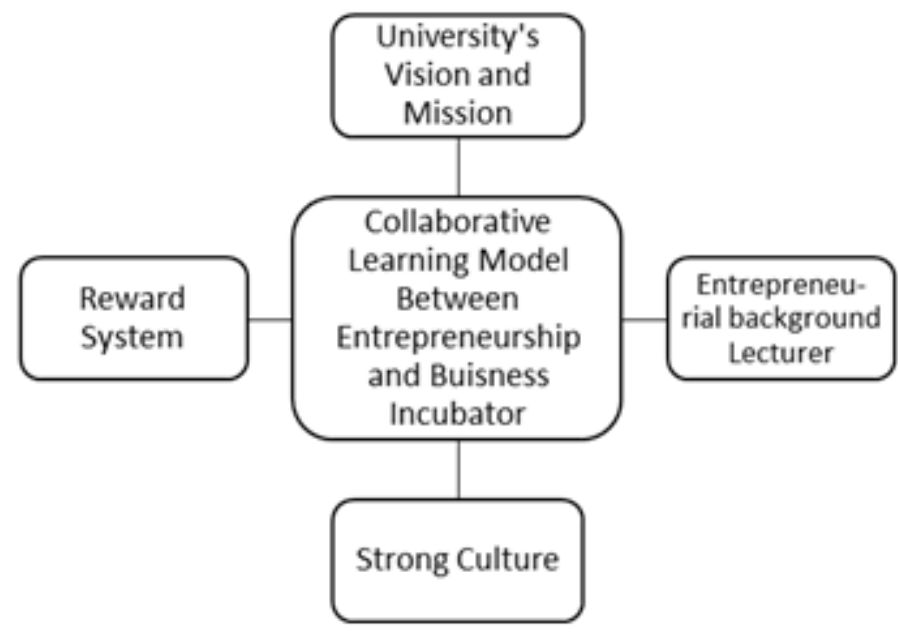

Figure 3. Collaborative learning model between entrepreneurship program and business incubator

As shown in Figure 3, desribes the emergent role of each aspect to make the model become effective in the higher education field.

\subsection{University Mission and Vission}

It is critical to establish the solid vision and mission from the university in related with the entrepreneurship implementation. The Vision and Mision become strong fundamental for all the supporting departments to perform the entrepreneurship program including measuring the program. As Karyana (2016), Yovita (2016) and Nurul (2016) studied that entrepreneur require hard work and obviously its require full support from the university, therefore, the university should design vision and mission relate to the entrepreneurship. Without clear university's visions and missions, thus, it difficult to develop entrepreneurship model. It is supported by one of FGD's participant which he argued that "the university play a vital role to create effective mechanism for the successful model. It is very hard for the lecture and incubator staff to run the program without it". He added that "The university support is critical to succeed the effective learning of entrepreneurship. The lecturers will comply with the university's policy to run any single program including for entrepreneurship and incubator, furthermore, the incubator must have a strong and clear concept to engage with university's mission and vision. It will stimulate both parties to create many programs that stimulate the students' passion and reward them for every effort they have shown". Furthermore, it is clearly 
stated that visions and mission between public university and private university is different and, this impact to sources that available to use to develop entrepreneurship model.

\subsection{Entrepreneurial Background of the Lecturers}

The lectures are strongly critical for the design of entrepreneurship program integrated with the business incubator. The competent lecturers are playing important role to train college students entrepreneurial awareness, entrepreneurial quality, entrepreneurship, entrepreneurial skills and entrepreneurial abilities.

\subsection{Strong Culture}

Without strong culture, the universities will face big obstacles and challenges to achieve effective entrepreneurship integrated wth its business incubator. Strong culture is the condicive environtment as well as the soul to execute entrepreneurship activities from the very small stage until the higher stage in higher educations. There are few empirical studies have examined the association between dimensions of culture and entrepreneurship at the national or regional level (Davidsson, 1995; Davids- son \& Wiklund, 1997). The studies above examined the association between Hofstede's dimensions of individualism and power-distance and national rates of innovation. It was concluded that individualism was positively associated and power-distance was negatively associated with national innova- tion rates, even after adjusting for the influence of national wealth.

As study finds that the university and the lecturer are very crucial to support the effectiveness of entrepreneurship and business incubator, therefore, the universities should establish enterpreneusrhip culture through potential lecturer. It would be resulted improve enterprenural skills and abilities as well as the quality of entrepreneurship. It is supported by one of FGD participant that "Lecturers are every important to make the succesful of entrepreneurship program. Beside that, environtment could shape the mindset of the students too".

\subsection{Reward System}

The university must be creative and inovative in creatiing the effective stimulies for the participants who are the students. The students with many projects and assigment come from other subjects are difficult to participate with many entrepreneurship program. The program must be designed with attarctive incentive, activities and measurable result for their prospective future.

\section{References}

Ardianti, Retno. (2009). Entrepreneurship Education in Indonesia's Higher Education Institutions: A Solution for Problems Faced by The Next Generation. London International Conference on Education (LICE), UK.

Bikse, Veronika, Inese Lusena-Ezera, Baiba Rivza, \& Tatjana Volkova. (2016). The Transformation of Traditional Universities into Entrepreneurial Universities to Ensure Sustainable Higher Education. Journal of Teacher Education for Sustainability, 18(2), 75-88. https://doi.org/10.1515/jtes-2016-0016

Binks, M., Starkey, K., \& Mahon, C.L. (2006). Entrepreneurship Education and the Business School. Technology Analysis \& Strategic Management, 18(1).

Calitz, M.G. (2009). Pilot study. University of South Africa, 256-289. https://doi.org/10.1097/IGC.0b013e3182842efa.End-of-Life

Chan, K., \& Lau, T. (2005). Assessing technology incubator programmes in the science park: the good, the bad and the ugly. Technovation, 25(10), 1215-1228.

Cheng, Ming Yu, Chan, Wai Sei, \& Mahmood, Amir. (2012). The Effectiveness of entrepreneurship education in Malaysia. Education Training, 51(7), 555-566. Emerald Group Publishing Limited. https://doi.org/10.1108/0040091091099275

Chiesa, V., \& Piccaluga, A. (2000). Exploitation and diffusion of public research: the case of academic spin-off companies in Italy. $R$ and D Manage, 30(4), 329-340.

Cresswell, John, W. (2013). Qualitative Inquiry and Research Design - Choosing Among Five Approaches ( ${ }^{\text {rd }}$ ed.). Los Angeles, CA: Sage Publications.

Davaris Angelo, Kokkinos, Dimitris, \& Fotopoulos, Anaxagoras. (2013). The impact of higher education institutes incubator/accelerator centres to technological education advancement: a review of selected case studies. World Transactions on Engineering and Technology Education (WIETE), 11(3).

Direktorat Jenderal Pendidikan Tinggi. (2009). Laporan PMW di Perguruan Tinggi (tidak dipublikasikan). Jakarta: Direktorat Kelembagaan. 
Direktorat Jenderal Pendidikan Tinggi. (2010). Pedoman Program Kreatifitas Mahasiswa. Direktur Penelitian dan Pengabdian kepada Masyarakat Direktorat Jenderal Pendidikan Tinggi, Depdiknas. Jakarta.

Drucker, P. F. (1985). Innovation and entrepreneurship: Practice and principles (1st Perennial Library ed.). New York: Perennial Library.

Etzkowitz H., Webster A., Gebhardt C., Brance R., \& Cantisano T. (2000). The future of the University and the University of the future: Evolution of ivory tower to entrepreneurial paradigm. Research Policy, 29(2), 313-330.

EC/OECD. (2012). A Guiding Framework for Entrepreneurial Universities. Final version 18 December 2012. Retrieved December $\quad 3, \quad 2015, \quad$ from http://www.oecd.org/site/cfecpr/EC-OECD\%20Entrepreneurial\%20Universities\%20Framework.pdf

Fatch, Muhamad. (2000). Inkubator Bisnis Universitas Brawijaya. Lembaga Pengabdian Masyarakat. Universitas Brawijaya.

Ge, Chao, \& LI, Xu (2015). The Strategies Analysis on Entrepreneurship Education in Colleges and Universities. Management \& Engineering Journal, 21, 36-39. https://doi.org/10.5503/J.ME.2015.21.006

Grimaldi, R., \& Grandi, A. (2005). Business incubators and new venture creation: an assessment of incubating models. Technovation, 25(2), 111-121.

Hackett, S.M., \& Dilts, D.M. (2004). A systematic review of Business Incubation Research. Journal of Technology transfer, 29, 55-82.

Joshi, Rajiv. (2014). Entrepreneurship Education: Core, Context and Challenges. Journal of Entrepreneurship and Management, 3(2).

Hadjimanolis, A. (2007). Entrepreneurship Education in Cyprus: From Humble Beginnings to a Promising Future?. Journal of Business and Society.

Katz, J. A. (2003). The chronology and intellectual trajectory of American entrepreneurship education. Journal of Business Venturing, 18(2), 283-300. https://doi.org/10.1016/S0883-9026(02)00098-8

Kuratko D. F. T. (2005). The Emergence of Entrepreneurship Education:Development, Trends, and Challenges. Entrepreneurship Theory and Practices.

Krueger, R. A., \& Casey, M. A. (2000). Focus groups: A practical guide for applied researchers (3rd ed.). Thousand Oaks, CA: Sage.

Cres, J., Millman, C., Sursani, S.R., Smith, K., \& Martin, L.M. (2006). Graduate entrepreneurship education in the United Kingdom. Education+Training, 48(8/9), 597-613.

Mudde, Huub L.M., Widhiani, Anita Primaswari, \& Fauzi, Anas Miftah. (2017, April). Entrepreneurial University Transformation in Indonesia: A Comprehensive Assessment of IPB. GSTF Journal on Business Review (GBR), $5(1)$.

National Business Incubation Association. (2013). 23 August 2013. Retrieved January, 2017, from http://www.nbia.org/

Solomon, G., Duffy, S., \& Tarabishy, A. (2002). The state of entrepreneurship education in the United States: a nationwide survey and analysis. International Journal of Entrepreneurship Education, 1(1), 65-86.

Storen, Liv-Anne. (2014). Entrepreneurship in higher education; Impacts on graduates' entrepreneurial intentions, activity and learning outcome. Journal of Education Training, 56(8/9), 795-813.

Suwandi. (2007, October). Pengembangan Model Inkubator Bisnis Perguruan Tinggi. Jurnal Penelitian Humaniora, 12(2), 65-86.

Paloniemi, Kaarlo, \& Belt, Pekka. (2012). Mismatch in Teachers' Ontological Conception of Entrepreneurship Education. Journal of Entrepreneurs, 11(2).

Rybnicek, Robert, Ruhri, Matthias, \& Suk, Katharina. (2015). How To Integrate Entrepreneurship Education And Creativity Into A Bureaucratic Environment (Case Study). 9th International Scientific Conference "Economic and Social Development", Istanbul, 9-10 April 2015.

Vesper, K., \& Gartner, W. (1998). University Entrepreneurship Programmes Worldwide. University of South Carolina, Los Angeles, CA.

Veronika, B., Inese, L.E., Baiba, R., \& Tatjana, V. (2016). The Transformation of Traditional Universities into 
Entrepreneurial Universities to Ensure Sustainable Higher Education. Journal of Teacher Education for Sustainability, 18(2), 77-88. https://doi.org/10.1515/jtes-2016-0016

Wilkinson, S. (2004). Focus group research. In D. Silverman (Ed.), Qualitative research: Theory, method, and practice (pp. 177-199). Thousand Oaks, CA: Sage.

Wiratno, Siswo. (2012). Pelaksanaan Pendidikan Kewirausahaan Di Pendidikan Tinggi. Jurnal Pendidikan dan Kebudayaan, 18(4).

Van Wijk, E., \& Harrison, T. (2013). Managing ethical problems in qualitative research involving vulnerable populations using a pilot study. International Journal of Qualitative Methods, 12(1), 570-586. 